block made of glass, weighing approximately four hundredweight. Mr. Geoffrey Pilkington, of Messrs. Pilkington Bros. Ltd., who cast the block, performed the ceremony in the presence of a distinguished gathering of civic and university authorities and prominent glass manufacturers. $\mathrm{He}$ said that he thought he must be the first to lay such a block, and referred to the considerable technical difficulties involved in its manufacture. Immediately previous to the laying of the block, Prof. W. F. S. Turner placed a glass casket containing appropriate records in a cavity in a wall of the building. He said, however, that as the Glass Research Delegacy was quite sure that the list of donors to the Building Fund enclosed was not yet complete, it was not proposed to seal either the casket or the cavity as yet. The prochancellor of the University, Lieut.-Colonel Sir Henry Stephenson, sketched the development of the Department from its birth in 1916, and Mr. Bagley, chairman of the Glass Delegacy, announced that of the sum required for the operations, only a further $£ 7,000$ now remains to be raised.

FollowiNG the laying of the foundation 'stone' for the new buildings, the Wood Memorial Library was declared open by Mr. Bagley who, after a prayer of dedication from the Bishop of Sheffield, spoke in moving terms of the work of the late Mr. Frank Wood for the Department of Glass Technology, through the Glass Research Delegacy, of which he was chairman from 1923 until his death in 1934. A beautiful memorial window in stained glass executed by Messrs. James Powell and Sons to the design of Mr. J. Hogan, was then unveiled by Mr. Haslam Wood, son of Mr. Frank Wood. A portrait of Mr. Wood in the centre is supported on the left by scenes illustrating glass manufacture and on the right by others showing research and control. Above are the shields of the Universities of Leeds, London and Sheffield, with a glass furnace below them.

\section{Sir Aurel Stein in Southern Persia}

Sir AUrel Stein described his latest and final journey of archæological reconnaissance in southern Persia before the Royal Asiatic Society and the Royal Central Asian Society on November 11. In recording his farewell to Iran, Sir Aurel mentioned that in five years he had covered close on five thousand miles on camel, horse and foot-a considerable achievement for any explorer, in view of the difficulties of climate, country and the dangers of tribal interference, but for a veteran past his eightieth year a feat of remarkable endurance. This last expedition, taking up its work where the expedition of exploration in Fars had come to an end in 1934, started from Shiraz in November 1935 and lasted until the autumn of 1936. Its itinerary included the plateau of Ardakhan, the Bakhtiari Mountains, Susa, the Saimareh River, to which four months was devoted, the little explored Pish-i-koh portion of Luristan, Kermanshah, the high mountain valleys of Persian Kurdistan, where an attempt to reach the border was unsuccessful, and the province of Urumiyeh, where in the country between Zagros and the salt Lake Urumiyeh, prehistoric remains in the form of mounds, both great and small, far exceeded in numbers any encountered in previous stages of the journey. Here burials in abundance belonging to the second millennium B.c. were found; but difficulties of labour, of which the supply was permanently depleted during the Great War, prevented any extensive investigation. The expedition came to an end at an interesting point, when the reconnaissance was being carried out in the valleys leading down from Kermanshah to the Mesopotamian plains. Orders from Teheran, due to the possibility of difficulties with the tribes, and the incipient illness of the leader, prevented the completion of the programme as planned. Sir Aurel, however, has no ground for dissatisfaction in what had been accomplished. A notable tale of archæological discoveries of every period from prehistoric to early Mohammedan has been added to his laurels.

\section{Archæological Exploration in Arabia}

Mr. H. Sт. John Philby opened up an attractive vista for archæological exploration in an account of his recent journey through Arabia before the Royal Geographical Society on November 15, when he suggested that the Sheban country might be the original homeland of the Phenicians whose place of origin has not yet been determined. In the summes and autumn of last year Mr. Philby traversed Arabia from north to south, from the Mediterranean to the Indian Ocean, a journey of which there is no previous record, although he himself considers that it may have been a route followed at times in the days of the old spice trade. To the archæologist, the most interesting part of Mr. Philby's lecture dealt with his visit to the ancient Himyaritic capital of Shabwa, where, however, he found no evidence to support Pliny's statement, if the identification of that writer's Sabota with Shabwa be accepted, that it had contained sixty temples. The remains of one outstanding temple of supreme magnificence was found, with two ruin heaps within the walls, which one day may be found to contain temples. At the same time there is a possibility, in Mr. Philby's view, that Pliny may have been referring to the whole district of the "two Shebas', which might well have possessed sixty temples in the days of its prosperity. In the heart of the desert two necropolises were discovered, forty miles away from the nearest wells to-day. Here there were thousands of circular tombs built up of untrimmed slabs of local limestone. The largest tomb was ten feet high and twenty-five feet in diameter. All the tombs had been rifled of their contents and in no instance was evidence of human burial discovered. Judging from the inscriptions, these tombs date from Himyaritic times or earlier. Similarities with cemeteries at Bahrain and in the central Arabian provinces point to Phenician affinities; while certain signs among the inscriptions and rock engravings seem to stand half-way between pictographs and letters, recalling the reputed relation of the Phenicians with the origins of the alphabet. 